\title{
Control of dormancy by lipid metabolism in Calanus finmarchicus: a population model test
}

\author{
Frédéric Maps ${ }^{1, *}$, Stéphane Plourde ${ }^{2}$, Bruno Zakardjian ${ }^{3}$ \\ ${ }^{1}$ School of Marine Sciences, University of Maine, Gulf of Maine Research Institute, 350 Commercial Street, Portland, \\ Maine 04101, USA \\ ${ }^{2}$ Maurice-Lamontagne Institute, Fisheries and Oceans Canada, 850 route de la Mer, C.P. 1000 Mont-Joli, Québec G5H 3Z4, \\ Canada \\ ${ }^{3}$ Laboratoire de sondages électromagnétiques de l'environnement terrestre (LSEET), Université du Sud Toulon - Var, \\ Bâtiment F, BP 20132, 83957 La Garde Cedex, France
}

\begin{abstract}
The life cycle of Calanus finmarchicus includes a prolonged dormancy phase that allows it to avoid the unfavourable environmental conditions typical of the upper ocean from late summer to early spring in the subarctic North Atlantic. Recent demographic, physiological and genetic evidence supports the hypothesis of a crucial role for lipid accumulation and metabolism in the control of dormancy. We present a stage-resolving biomass model of $C$. finmarchicus, implementing a mechanistic approach of the control of dormancy based on this lipid hypothesis. The dormancy process obeys 2 rules: (1) active copepodite stage Vs (C5s) enter dormancy when the ratio of lipid to total body carbon exceeds some threshold, and (2) diapausing C5s exit dormancy when their lipid storage approaches a lower threshold. We implemented the model into a 1-dimensional water column framework and compared our results to 2 consecutive years of observations of stage-specific copepodite abundances and lipid content of C5 from the Northwest Gulf of St. Lawrence, Canada. The model produced realistic phenology and temporal patterns in lipid content of C. finmarchicus in response to the observed environmental forcing. Interannual variations in the timing of entry and contributions of different generations to the overwintering stock were shown. Our results are consistent with the hypothesis of a lipid-mediated control of entrance and exit from dormancy in C. finmarchicus.
\end{abstract}

KEY WORDS: Calanus finmarchicus · Dormancy $\cdot$ Lipid $\cdot$ Numerical modeling $\cdot$ Gulf of St. Lawrence

\section{INTRODUCTION}

The pelagic copepod Calanus finmarchicus thrives across the subarctic North Atlantic Ocean. Its life cycle is divided between a period of active growth and reproduction within the productive surface layer during spring and summer, and an extended overwintering period (dormancy) at depth, essentially as copepodite stage V $(\mathrm{C} 5$; Hirche 1996a, b). The phenology of C. finmarchicus shows regional plasticity at the scale of the North Atlantic, as evidenced by 3 region-specific seasonal maxima in population size in surface waters (Planque et al. 1997). Such differences in phenology are also observed over a smaller spatial scale with the timing of initiation and termination of dormancy varying by several weeks to months on the continental shelf in the Northwest Atlantic (Johnson et al. 2008). Normal versus exceptional variability in the timing of emergence from dormancy affects higher trophic levels relying on the supply of copepod biomass during spring (e.g. Ringuette et al. 2002, Mackas et al. 2007).

The relationships between the key environmental parameters (temperature and food) and physiological processes (growth, development and egg production) of the growing development stages of Calanus finmarchicus are relatively well characterized from various laboratory, mesocosm and in situ studies (e.g. Harris et al. 2000, Campbell et al. 2001). However, no such extensive knowledge exists concerning the factors controlling the dynamics of the dormancy phase of the 
life cycle. Johnson et al. (2008, p 438) concluded that in the Northwest Atlantic 'no consistent pattern in the gradients of environmental cues [...] could explain the observed dormancy entrance and exit patterns'. Meanwhile, modelling studies showed the inability of simple trigger mechanisms to explain the timing of entrance in dormancy at the scale of the North Atlantic (e.g. Speirs et al. 2006). This lack of clear understanding of the controls of dormancy led previous modellers to: (1) impose either the date of its initiation or the fraction of each generation entering dormancy, and (2) impose the date of its termination in order to simulate the targeted phenology (Carlotti \& Wolf 1998, Lynch et al. 1998, Miller et al. 1998a, Tittensor et al. 2003, Zakardjian et al. 2003, Speirs et al. 2006, Slagstad \& Tande 2007). Such approaches preclude sensitivity studies of C. finmarchicus population dynamics to interannual or long-term variations in environmental forcing. However, a few studies have proposed mechanistic explanations of dormancy. Fiksen (2000) added 3 model 'genes' to C. finmarchicus individuals, in which there is a rule for entry into dormancy involving the lipid to somatic tissue ratio, and exit from dormancy is forced by the day length. Hind et al. (2000) assumed that dormancy duration was controlled by the normal development processes operating at a reduced rate, after it was initiated by a low-food availability threshold. However, this dormancy control failed to reproduce the large variations in phenology across the spatial range of C. finmarchicus (Speirs et al. 2006).

Recent physiological (Jónasdóttir 1999, Miller et al. 2000, Rey-Rassat et al. 2002, Hassett 2006, Saumweber \& Durbin 2006), genetic (Tarrant et al. 2008) and demographic (Johnson et al. 2008) evidence supports the hypothesis of a crucial role for lipid accumulation and metabolism in the control of dormancy (Irigoien 2004, Saumweber \& Durbin 2006, Johnson et al. 2008). High amounts of wax esters, mostly confined to the individual's oil sac, are observed during the dormancy period (Miller et al. 1998b, Ingvarsdóttir et al. 1999, Jónasdóttir 1999, Saumweber \& Durbin 2006). A significant proportion of lipid storage remains at the end of the dormancy period in stage C5 to support the metabolic costs associated with gonad maturation, the moult to adult stages and the ontogenetic vertical migration of adult females from the overwintering depths to the surface layer (Jónasdóttir 1999, Rey-Rassat et al. 2002, Saumweber \& Durbin 2006). Johnson et al. (2008) have argued for some threshold level of lipid storage above which dormancy can be initiated in order to support the metabolic requirement during the dormancy period and the maturation process at the time of moulting. The rationale is that individuals entering dormancy without enough lipids to meet these requirements would eventually experience high mortality because of starvation either at depth or after migrating to the surface in unfavorable environmental conditions. Along this hypothesized lipid-driven dormancy mechanism, it is possible for other cues to influence the time of exit from dormancy. These cues could be either internal through hormonal control, or external like the stimulating effect of the advection bringing back individuals to the surface layer, as suggested by some observations and incubation experiments, especially in coastal areas (e.g. Durbin et al. 1997).

In a few individual-based models whose formulation allows for a finer exploration of the numerous metabolism pathways and matter and energy compartments involved, the role of lipids in controlling the dormancy phase appeared essential (Carlotti \& Wolf 1998, Fiksen \& Carlotti 1998, Fiksen 2000, A. W. Leising et al. unpubl. data). To our knowledge, the present study represents the first attempt to test a mechanistic approach based entirely on lipid accumulation and metabolism for the control of dormancy of Calanus finmarchicus at the population level, allowing for ease of coupling to general circulation models. We adapted the stageresolving biomass population model of copepods developed by Fennel (2001) and modified by Stegert et al. (2007) to C. finmarchicus. In our model, the dormancy process obeyed 2 rules: (1) active stage C5 enter dormancy when their ratio of lipid to total body carbon exceeds a specified threshold value, and (2) diapausing stage C5 exit dormancy when their lipid storage approaches a lower threshold. We implemented the model in a 1-dimensional (1-D) water column framework and compared our results to observations of abundance of copepodite stages, body carbon and lipid contents of stage C5 from 3 monitoring stations located in the Gulf of St. Lawrence (GSL), eastern Canada.

\section{METHODS}

We developed a stage-resolving biomass model for Calanus finmarchicus following Fennel (2001) and Stegert et al. (2007). The model computed for each stage $i$ biomass $\left(B_{i}\right)$ and abundance $\left(N_{i}\right)$ and the resulting mean individual mass $\left(m_{i}=B_{i} / N_{i}\right)$. According to the concept developed by Carlotti \& Sciandra (1989), the stage-specific critical moulting mass (CMM) is the mass threshold above which transfer (moulting) to the next stage occurs. Therefore, in our model the development of the stages resulted from the interplay between stage-specific CMM and growth, both varying according to food and temperature. Detailed formulations of CMM, growth and transfer rates are given in the following sections. All equations and parameters are presented in Tables 1 \& 2. We considered the egg and nauplius N1-2 stages as a non-growing stage and 
Table 1. Calanus finmarchicus. State variables and equations used to simulate the temporal and spatial evolution of those state variables. N1-3: nauplii stage I to II; C4-6: copepodite stage IV to VI: C5d: diapausing C5; C6f, C6m: C6 females and males, respectively. $T$ : temperature $\left({ }^{\circ} \mathrm{C}\right) ; F$ : food $\left(\mu \mathrm{g} \mathrm{C} l^{-1}\right)_{;} t$ : time (h)

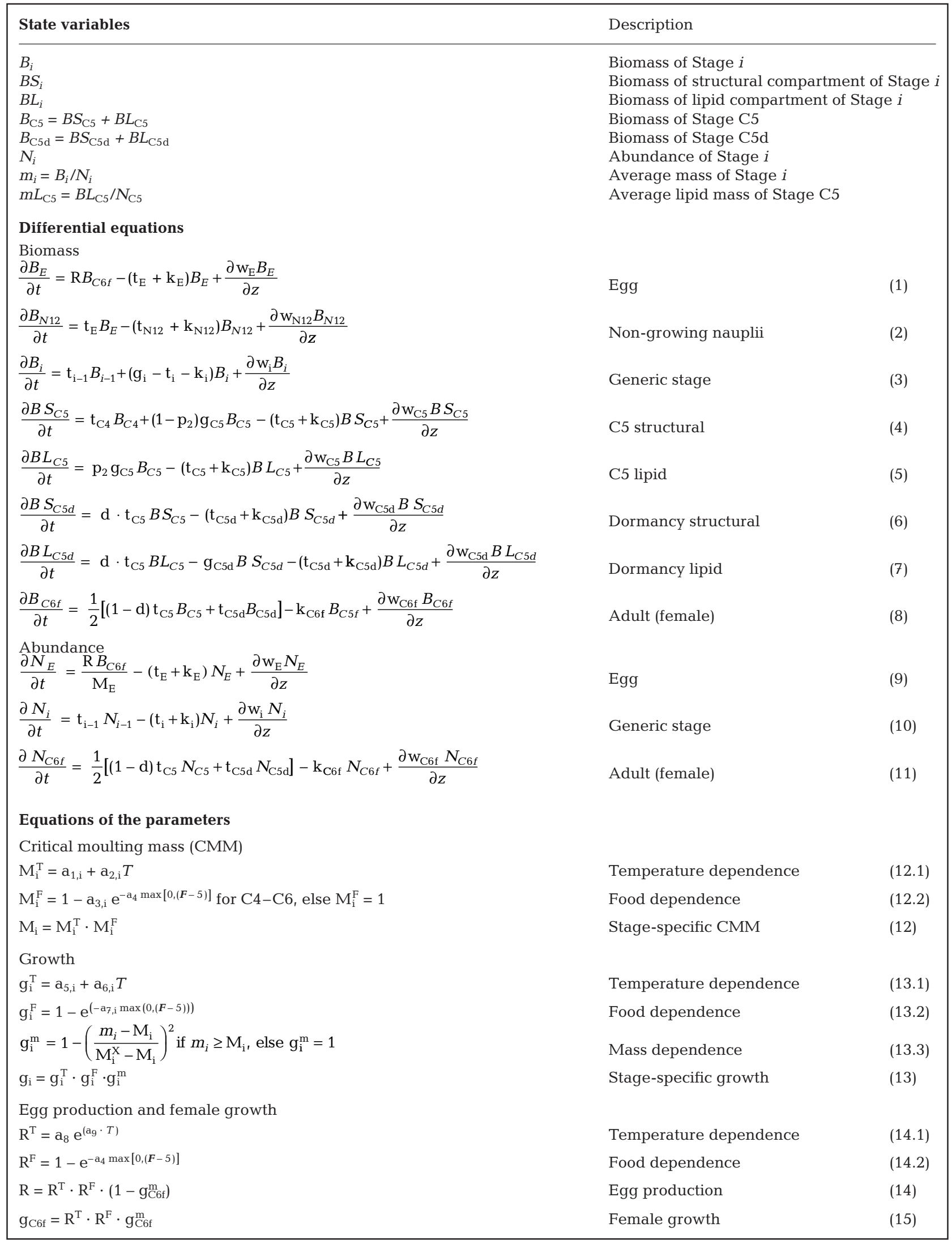


Table 1 (continued)

\begin{tabular}{|c|c|c|}
\hline \multicolumn{3}{|l|}{ Transfer from stage to stage } \\
\hline $\mathrm{t}_{\mathrm{i}}=\frac{1}{\mathrm{a}_{10, \mathrm{i}}(T+9.11)^{-2.05}}$ if $T>0$, else $_{\mathrm{i}}=0$ & Non-growing stages & $(16.1)$ \\
\hline $\mathrm{t}_{\mathrm{i}}=\frac{\left(m_{i}-\mathrm{M}_{\mathrm{i}}^{\mathrm{t}}\right)^{3}}{\left(m_{i}-\mathrm{M}_{\mathrm{i}}^{\mathrm{t}}\right)^{3}+\left(\mathrm{M}_{\mathrm{i}}^{\mathrm{X}}-\mathrm{M}_{\mathrm{i}}^{\mathrm{t}}\right)^{3}}$ if $m_{i} \geq \mathrm{M}_{\mathrm{i}}^{\mathrm{t}}$, else $\mathrm{t}_{\mathrm{i}}=0$ & Growing stages & $(16.2)$ \\
\hline $\mathrm{t}_{\mathrm{C} 5 \mathrm{~d}}=\frac{\left(\mathrm{M}_{\mathrm{C} 5 \mathrm{~d}}^{\mathrm{t}}-m_{C 5 d}\right)^{3}}{\left(\mathrm{M}_{\mathrm{C} 5 \mathrm{~d}}^{\mathrm{t}}-m_{C 5 d}\right)^{3}+\left(\mathrm{M}_{\mathrm{C} 5 \mathrm{~d}}^{\mathrm{t}}-\mathrm{M}_{\mathrm{C} 5 \mathrm{~d}}^{\mathrm{X}}\right)^{3}}$ if $m_{C 5 d} \leq \mathrm{M}_{\mathrm{C} 5 \mathrm{~d}}^{\mathrm{t}}$, else $\mathrm{t}_{\mathrm{C} 5 \mathrm{~d}}=0$ & Dormancy stage & $(16.3)$ \\
\hline $\begin{array}{l}\text { Dormancy } \\
\mathrm{d}=\frac{\left(\mathrm{r}_{\mathrm{L}}-0.9 \mathrm{p}_{1}\right)^{2}}{\left(\mathrm{r}_{\mathrm{L}}-0.9 \mathrm{p}_{1}\right)^{2}+\left(\mathrm{p}_{1}-0.9 \mathrm{p}_{1}\right)^{2}} \text { if } \mathrm{r}_{\mathrm{L}}=\frac{m L_{C 5}}{m_{C 5}} \geq 0.9 \mathrm{p}_{1} \text {, else } \mathrm{d}=0\end{array}$ & Lipid dependence & $(17)$ \\
\hline \multicolumn{3}{|l|}{ Mortality of non-feeding stages } \\
\hline $\mathrm{k}_{\{\mathrm{E}, \mathrm{N} 12\}}=\mathrm{a}_{11}+\mathrm{a}_{12} \int_{\text {bott. }}^{\text {surf. }} N_{C 6 f}$ if $\int_{\text {bott. }}^{\text {surf. }} N_{C 6 f} \geq 2000 \mathrm{~m}^{-2}$, else $\mathrm{k}_{\{\mathrm{E}, \mathrm{N} 12\}}=0.5$ & Density dependence & $(18)$ \\
\hline $\begin{array}{l}\text { Swimming behaviour } \\
\mathrm{z}_{\mathrm{i}}^{\mathrm{mig}}=\mathrm{z}_{\mathrm{i}}^{\text {sup }}+\Delta \mathrm{z}_{\mathrm{i}}\left\{1-\tanh \left[3 \cdot \cos \left(2 \pi \frac{\boldsymbol{t}+4}{24}\right)\right]\right\}\end{array}$ & Optimal depth & $(19.1)$ \\
\hline $\begin{aligned} z_{i} & =z_{i}^{\text {mig }} \text { for migrating stages, else see Table } 2 \\
\varepsilon & =\operatorname{sign}\left\{\frac{1}{2}-U[0,1]\left[1-\left(\frac{z-z_{i}}{15}\right)^{2}\right]\right\}\end{aligned}$ & Stochastic parameter & $(19.2)$ \\
\hline $\mathrm{w}_{\mathrm{i}}=\mathrm{w}_{\mathrm{i}}^{\mathrm{X}} \cdot \tanh \left[\mathrm{a}_{13}\left(z-\mathrm{z}_{\mathrm{i}}\right)\right] \cdot \varepsilon$ & Swimming speed & (19) \\
\hline
\end{tabular}

all subsequent development stages (N3-C6) separately. Moulting C5s were equally allocated to males (C6m) and females (C6f) according to a sex-ratio of 1:1. Finally, we defined a diapausing stage (C5d). The behaviour of the model was first tested in an idealized 0 -dimensional (0-D) framework. The model was then implemented in 1-D in order to explore its response to the vertical environmental structure typical of the GSL. The 1-D modelled domain was $300 \mathrm{~m}$ deep, with a vertical resolution of $5 \mathrm{~m}$ and a time step of $5 \mathrm{~min}$. Initial conditions assumed an early winter population of C5d spread within a depth range of 200 to $300 \mathrm{~m}$, with a realistic integrated abundance of 15000 ind. $\mathrm{m}^{-2}$ (Plourde et al. 2001, Harvey et al. 2005), a body mass of $200 \mu \mathrm{g}$ of carbon and a ratio of lipid to body mass of $50 \%$ on 1 January 1999.

Environmental forcing. We used environmental data from the Atlantic Zone Monitoring Program (AZMP) conducted by Fisheries and Oceans Canada (Therriault et al. 1998). We forced the 1-D model with profiles of temperature and chlorophyll a (chl a) collected during 2 consecutive years (1999-2000) at 2 monitoring stations located in the Anticosti Gyre (AG) and Gaspé Current (GC) in the northwest GSL (Fig. 1). Data were collected on a fortnightly basis. They were linearly interpolated in space and time and averaged to construct profiles representative of the northwest GSL environment (see Fig. 2).
Vertical distribution and migrations. The actively growing stages are mostly observed within the first $10 \mathrm{~s}$ of meters of the water column above a cold intermediate layer (CIL, defined here by the $2^{\circ} \mathrm{C}$ isotherm) and well above the deep-dwelling diapausing individuals (Plourde et al. 2001, Head \& Pepin 2007). Late copepodite and adult stages of Calanus finmarchicus perform diel vertical migrations (DVM) between the surface and the bottom of the CIL. DVM are associated with a diel feeding rhythm in summer in the lower estuary (Simard et al. 1985). The stage-specific swimming speed was defined as the product of: (1) a maximum swimming velocity of one body length per second for nauplii and 3 for the copepodites; (2) a depthdependent function leading to downward (upward) swimming when copepods were above (below) a target depth (Zakardjian et al. 1999); and (3) a random dispersion term in order to avoid unrealistic concentrations in thin layers. The targeted depth was stagespecific (Table 2) with nauplius and young copepodite stages $(\mathrm{C} 1-3)$ remaining close to the surface and $\mathrm{C} 4$, C5 and C6f performing DVM between the depth of maximum chl a biomass at midnight and $100 \mathrm{~m}$ at noon (Plourde et al. 2001). Under our formulation, the $24 \mathrm{~h}$ period was divided in two $8 \mathrm{~h}$ periods, either at their daytime or night-time target depth, separated by a $4 \mathrm{~h}$ transition period. A first-order Eulerian forward scheme was used to compute the evolution of the state vari- 
Table 2. Calanus finmarchicus. Parameter descriptions, units and values. $\leftarrow$ : same as left; nd: not defined; var.: variable (see text)

\begin{tabular}{|c|c|c|c|c|c|c|c|c|c|c|c|c|c|c|c|c|}
\hline \multicolumn{2}{|c|}{$\begin{array}{l}\text { Para- } \\
\text { meter Description }\end{array}$} & Units & Egg & N1-2 & N3 & N4 & N5 & N6 & $\mathrm{C} 1$ & $\begin{array}{l}\text { Stage } \\
\text { C2 }\end{array}$ & $\mathrm{C} 3$ & $\mathrm{C} 4$ & C5 & C5d & C6f & C6m \\
\hline \multicolumn{17}{|c|}{ Critical moulting mass (CMM) } \\
\hline $\mathrm{a}_{1, \mathrm{i}}$ & Temperature constant & $\mu g \mathrm{C}$ & 0.23 & 0.23 & 0.5 & 0.76 & 1.14 & 1.8 & 3.4 & 9.4 & 28.9 & 94 & 332 & nd & 262 & nd \\
\hline $\mathrm{a}_{2, \mathrm{i}}$ & Temperature coefficient & $\mu g^{\circ} \mathrm{C}^{-1}$ & 0 & $\leftarrow$ & $\leftarrow$ & $\leftarrow$ & $\leftarrow$ & $\leftarrow$ & -0.06 & -0.28 & -1.09 & -4.71 & -18.8 & nd & -6.26 & nd \\
\hline$a_{3, i}$ & Food coefficient & & 0 & $\leftarrow$ & $\leftarrow$ & $\leftarrow$ & $\leftarrow$ & $\leftarrow$ & $\leftarrow$ & $\leftarrow$ & $\leftarrow$ & 0.25 & 0.5 & nd & 0.5 & nd \\
\hline $\mathrm{a}_{4}$ & Shape coefficient & $\mathrm{m}^{3} \mathrm{mg}^{-1}$ & nd & nd & 0.02 & $\leftarrow$ & $\leftarrow$ & $\leftarrow$ & $\leftarrow$ & $\leftarrow$ & $\leftarrow$ & $\leftarrow$ & $\leftarrow$ & $\leftarrow$ & $\leftarrow$ & $\leftarrow$ \\
\hline \multicolumn{17}{|c|}{ Growth } \\
\hline $\mathrm{a}_{5, \mathrm{i}}$ & Temperature constant & $\mathrm{d}^{-1}$ & nd & nd & 0.015 & $\leftarrow$ & $\leftarrow$ & $\leftarrow$ & 0.07 & 0.065 & 0.05 & 0.055 & 0.025 & 0.005 & 0.025 & nd \\
\hline$a_{6, i}$ & Temperature coefficient & $\mathrm{d}^{-1}{ }^{\circ} \mathrm{C}^{-1}$ & nd & nd & 0.025 & $\leftarrow$ & $\leftarrow$ & $\leftarrow$ & 0.14 & 0.028 & 0.027 & 0.015 & 0.01 & 0 & 0.01 & nd \\
\hline$a_{7, i}$ & Shape coefficient & $\mathrm{m}^{3} \mathrm{mg}^{-1}$ & nd & nd & 0.04 & $\leftarrow$ & $\leftarrow$ & $\leftarrow$ & 0.03 & $\leftarrow$ & $\leftarrow$ & 0.02 & $\leftarrow$ & nd & 0.02 & nd \\
\hline $\mathrm{M}_{\mathrm{i}}^{\mathrm{X}}$ & Maximum mass & $\mu \mathrm{g} \mathrm{C}$ & $1.1 \mathrm{M}_{\mathrm{i}}$ & $\leftarrow$ & $\leftarrow$ & $\leftarrow$ & $\leftarrow$ & $\leftarrow$ & $\leftarrow$ & $\leftarrow$ & $\leftarrow$ & $\leftarrow$ & $\leftarrow$ & $0.9 \mathrm{M}_{\mathrm{i}}$ & i $\quad 1.1 \mathrm{M}_{\mathrm{i}}$ & nd \\
\hline$p_{2}$ & Allocation of growth to lipid & & nd & nd & nd & nd & nd & nd & nd & nd & nd & nd & Fitted & nd & nd & nd \\
\hline \multicolumn{17}{|c|}{ Egg production } \\
\hline$a_{8}$ & Temperature coefficient & $d^{-1}$ & nd & nd & nd & nd & nd & nd & nd & nd & nd & nd & nd & nd & -0.02198 & 8 nd \\
\hline $\mathrm{a}_{9}$ & Shape coefficient & ${ }^{\circ} \mathrm{C}^{-1}$ & nd & nd & nd & nd & nd & nd & nd & nd & nd & nd & nd & nd & 0.116 & nd \\
\hline \multicolumn{17}{|c|}{ Transfer } \\
\hline $\mathrm{a}_{10, \mathrm{i}}$ & Belehrádek coefficient & $\mathrm{d}$ & 595 & 969 & nd & nd & nd & nd & nd & nd & nd & nd & nd & nd & nd & nd \\
\hline $\mathrm{M}_{\mathrm{i}}^{\mathrm{t}}$ & Transfer mass & $\mu g \mathrm{C}$ & nd & nd & $0.9 \mathrm{M}_{\mathrm{i}}$ & $\leftarrow$ & $\leftarrow$ & $\leftarrow$ & $\leftarrow$ & $\leftarrow$ & $\leftarrow$ & $\leftarrow$ & $\leftarrow$ & $1.1 \mathrm{M}_{\mathrm{i}}$ & i $\quad 0.9 \mathrm{M}_{\mathrm{i}}$ & nd \\
\hline \multicolumn{17}{|c|}{ Dormancy } \\
\hline$p_{1}$ & Lipid ratio threshold & & nd & nd & nd & nd & nd & nd & nd & nd & nd & nd & Fitted & nd & nd & nd \\
\hline \multicolumn{17}{|c|}{ Mortality } \\
\hline $\mathrm{k}_{\mathrm{i}}$ & Constant & $\mathrm{d}^{-1}$ & nd & nd & 0.25 & 0.15 & 0.1 & 0.08 & 0.05 & 0.04 & 0.03 & 0.03 & 0.02 & 0.002 & 0.02 & 0.04 \\
\hline$a_{11}$ & Base mortality & $\mathrm{d}^{-1}$ & 0.35 & 0.35 & nd & nd & nd & nd & nd & nd & nd & nd & nd & nd & nd & nd \\
\hline $\mathrm{a}_{12}$ & Density coefficient & $\mathrm{m}^{2}$ ind..$^{-1}$ & $8 \times 10^{-5}$ & $8 \times 10^{-5}$ & nd & nd & nd & nd & nd & nd & nd & nd & nd & nd & nd & nd \\
\hline \multicolumn{17}{|c|}{ Swimming behaviour } \\
\hline $\mathrm{z}_{\mathrm{i}}^{\text {sup }}$ & Minimum depth & $\mathrm{m}$ & nd & 5 & 5 & 5 & 5 & 5 & 5 & 5 & 5 & var. & var. & 150 & var. & 50 \\
\hline $\mathrm{z}_{\mathrm{i}}^{\text {inf }}$ & Maximum depth & $\mathrm{m}$ & nd & nd & nd & nd & nd & nd & nd & nd & nd & 100 & 100 & 250 & 100 & 150 \\
\hline $\mathrm{w}_{\mathrm{i}}^{\mathrm{X}}$ & Maximum speed & $\mathrm{m} \mathrm{h}^{-1}$ & 0.3 & 1 & 1.1 & 1.6 & 2.2 & 2.7 & 3.2 & 4.7 & 6.1 & 7.6 & 9.4 & 9.4 & 10.8 & 10.8 \\
\hline $\mathrm{a}_{13}$ & Shape coefficient & & nd & 0.03 & $\leftarrow$ & $\leftarrow$ & $\leftarrow$ & $\leftarrow$ & $\leftarrow$ & $\leftarrow$ & $\leftarrow$ & $\leftarrow$ & $\leftarrow$ & $\leftarrow$ & $\leftarrow$ & $\leftarrow$ \\
\hline
\end{tabular}

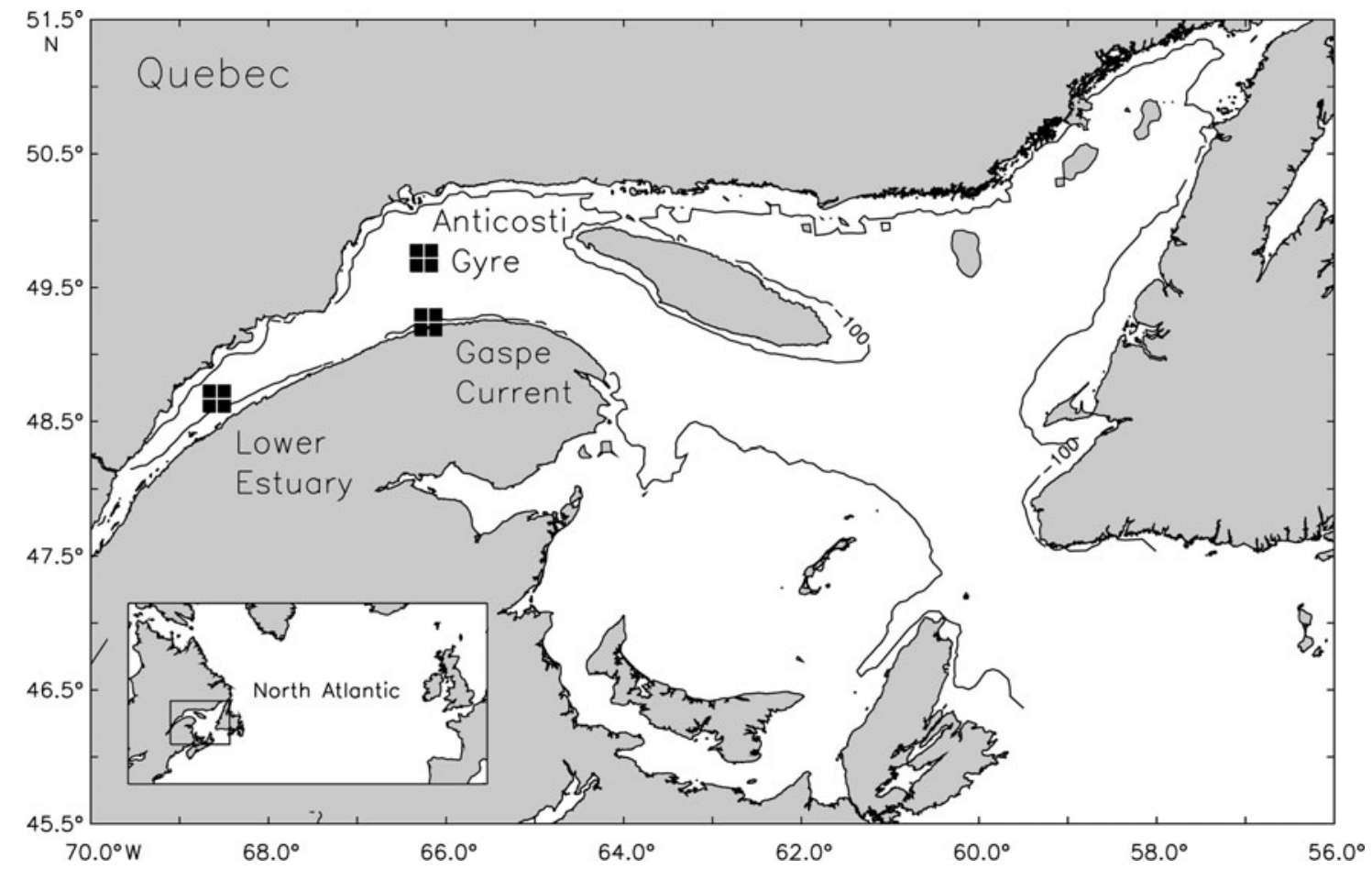

Fig. 1. Location of the 3 monitoring stations in the northwestern Gulf of St. Lawrence (GSL) providing forcing and validation data for the 1-dimensional simulations: Lower Estuary (Rimouski), Gaspé Current (GC) and Anticosti Gyre (AG) 
ables (biomass and abundance) with time. This scheme is conservative, stable, fast, monotonicity-preserving and compatible (Lipscomb \& Hunke 2004). Under this scheme, the computation of the ratio of biomass over abundance (i.e. the mean body mass) did not produce spurious values (e.g. Christian 2007).

Critical moulting mass (CMM). Constant CMMs for the egg and nauplii stages were taken from the literature (Runge \& Plourde 1996, Harris et al. 2000, Hygum et al. 2000a), whereas copepodites' CCMs were a function of temperature (Campbell et al. 2001). Our model considered the effect of food limitation on growth and development of C4, C5 and C6f stages, as low food concentrations induce a significant reduction of the carbon content in these stages relative to individuals of the same body length at high food concentrations (e.g. Hygum et al. 2000b). Food concentrations $<50 \mu \mathrm{C} \mathrm{Cl}^{-1}$ were considered limiting for growth, resulting in a $25 \%$ reduction in the CMM of $\mathrm{C} 4$ and a $50 \%$ reduction in the CMM of C5 and C6f (Campbell et al. 2001). The stagespecific relationship between temperature, food and CMM is essential for the coupling between growth and development. It appeared inappropriate to compute stage-specific CMM from the local conditions of temperature and food, as frequent vertical migrations across strong gradients would occur in late development stages performing DVM. Spurious transfer from one stage to the next would occur as soon as the locally computed CMM would fall below the actual mean body mass of the stage. Hence for surface dwelling stages (nauplii and C1-3), CMM was a function of the temperature and food concentration encountered at the target depth $(5 \mathrm{~m})$. For migrating stages (C4-5 and C6f), CMM was a function of the median temperature and maximum food concentration encountered between their night-time and daytime preferential depths.

Growth. Stage-specific growth rates were formulated as a function of temperature and food carbon concentration (Campbell et al. 2001). A carbon:chl a ratio of 55 was used to convert chl a biomass observed in the northwest GSL into carbon (Rivkin et al. 1996). Growth was further modulated by a parabolic function of the mean individual mass, ensuring that no growth occurred when the mean body mass exceeded the maximum body mass of the stage (Stegert et al. 2007). In analogy with a diel feeding rhythm, daily growth was completed during the period spent in the surface layer between 20 and $4 \mathrm{~h}$ (e.g. Simard et al. 1985, Durbin et al. 1995, Irigoien et al. 1998).

Egg production. Mass-specific egg production rate (EPR) was a function of temperature and carbon concentration (Hirche et al. 1997). The egg carbon content was set to $0.23 \mu \mathrm{g}$ (Runge \& Plourde 1996). Egg laying was assumed to occur only at night when the females were close to the surface (Runge \& Plourde 1996).
Newly moulted C6f were allowed to grow in order to reach their maximum mass at maturity. The amount of time required can be seen as a 'maturation' delay of a few days (Plourde \& Runge 1993). The C6f growth rate was equal to the mass-specific EPR.

Transfer. The transfer rate of biomass from one stage to the next was a function of the mean individual mass of the stage. A sigmoid function was used to prevent transfers of individuals before the stage reached $90 \%$ of its CMM (Stegert et al. 2007). For non-feeding N1-2, the transfer rate of biomass from one stage to the next was simply the inverse of the development duration of the stage, formulated as a Belehrádek temperature function (Campbell et al. 2001).

Mortality. We used constant stage-specific mortality rates decreasing exponentially from N3 to adults within the range of mortalities observed for Calanus finmarchicus in different regions (Ohman et al. 2004). The potential effect of cannibalism by adult females on the egg and N1-2 stages was taken into account. We used the function relating mortality in these early stages to adult female abundance given by Ohman et al. (2002). The mortality rate in C5d was $10 \%$ of daily mortality in non-diapausing C5 (McLaren et al. 2001, Gislason et al. 2007). The mortality rate in C6m was twice the mortality rate of C6f (Kiørboe 2006).

Dormancy. Stage C5 was divided into active (C5) and diapausing (C5d) categories. For each of these categories, biomass was divided into structural and lipid compartments. When transferring to $\mathrm{C} 5$, the biomass of C4 contributed only to the structural compartment of C5. The growth of C5 was divided between lipid and structural compartments according to a constant allocation coefficient, $p_{1}$. A parabolic function of the ratio of lipid carbon to total body carbon drove the transfer of C 5 toward either C $5 \mathrm{~d}$ or adults so that $50 \%$ of C 5 transferred to $\mathrm{C} 5 \mathrm{~d}$ when this ratio reached a constant threshold, $p_{2}$. In the absence of adequate published data to determine these important parameters, $p_{1}$ and $p_{2}$ were set as free parameters selected within the uniform distributions $p_{1} \sim \mathrm{U}(0.5,1)$ and $p_{2} \sim \mathrm{U}(0,1)$ according to an optimization procedure described below. Lipid accumulated by active $\mathrm{C} 5$ fueled the metabolic demand of the non-feeding C5d stage. Growth rate in C5d was negative and corresponded to the demand of the structural tissues upon the lipid storage. A constant basal metabolic rate derived from respiration rate of diapausing Calanus finmarchicus at $5^{\circ} \mathrm{C}$ was applied (Ingvarsdóttir et al. 1999). As a result, the mass-dependent transfer function of biomass and individuals from C5d to $\mathrm{C} 6$ increased as the mean body mass decreased toward a lower body mass threshold. This threshold was defined as the structural mass at the time of entrance into dormancy, plus a residual amount of lipid corresponding to half the structural mass. 
Optimization of the free parameters. The optimal set of free parameters $\left\{p_{1}, p_{2}\right\}$ was chosen by running simulations within the parameters' space in order to minimize the product of the root mean square deviations (RMSD) computed for the abundance of each copepodite stage, which represent the mean deviation of the simulated values compared to the observations (Piñeiro et al. 2008). All other parameters were held constant (Tables 1 \& 2). We used Calanus finmarchicus demographic data from the AZMP (see Harvey et al. 2005 for zooplankton sampling details) for 1999-2000 at the AG and GC stations for optimization of the model results (Fig. 1).

Sensitivity analysis. We performed a sensitivity analysis of our model to critical demographic parameters, namely the mortality in the early stages (egg and N1-2) and in C6f, and to the parameters influencing the dormancy timing and duration. Those parameters were the proportion of the growth of $\mathrm{C} 5$ allocated to lipids $\left(p_{1}\right)$, the ratio of lipid carbon to total carbon threshold driving the transfer to $\mathrm{C} 5 \mathrm{~d}$ $\left(p_{2}\right)$ and the rate of consumption of lipids in C5d. We computed the RMSD of the abundance of $\mathrm{C} 5 \mathrm{~d}$ from the simulations run with parameters altered by $\pm 10 \%$ with respect to a base simulation.

Validation. Whereas abundance data were used to optimize the free parameters, lipid and body mass observations served as independent control variables to assess the performance of the model. Total and lipid carbon content in C5 were estimated indirectly following Miller et al. (2000) and Saumweber \& Durbin (2006) using formalinpreserved C5. A comparison of these estimates made on preserved and fresh individuals showed that the lipid volume of preserved individuals was on average underestimated by 10\% (Plourde et al. unpubl. data). The measurements were made on $\mathrm{C} 5$ collected at the AG station in 1999 and 2000 and at a deep station (Rimouski) located in the St. Lawrence estuary sampled from spring to late autumn in both 1999 and 2000 (Fig. 1). Whereas abundance patterns of Calanus finmarchicus could be markedly different between the Rimouski and the AG and GC stations in the northwest GSL (Plourde et al. 2001, Harvey et al. 2005), the carbon and lipid conditions of the individuals proved to be more homogeneous at this regional scale. Estimations of entrance into and termination of dormancy from the time series of developmental stage proportions were also made. Following Johnson et al. (2008), the dormancy onset period was defined as the date when the proportion of $\mathrm{C} 5 \mathrm{~s}$ in the population rose to half its yearly maximum proportion, while the start of the emergence period was defined as the first date when adults comprised $>10 \%$ of the population.

\section{RESULTS}

\section{0-D simulations}

Development

A 0-D implementation of the model at different temperatures under non-limiting food conditions resulted in realistic equiproportional stage durations from N3 to adults (Fig. 2A). The absence of numerically generated 'premature moulting' in the model is illustrated by the
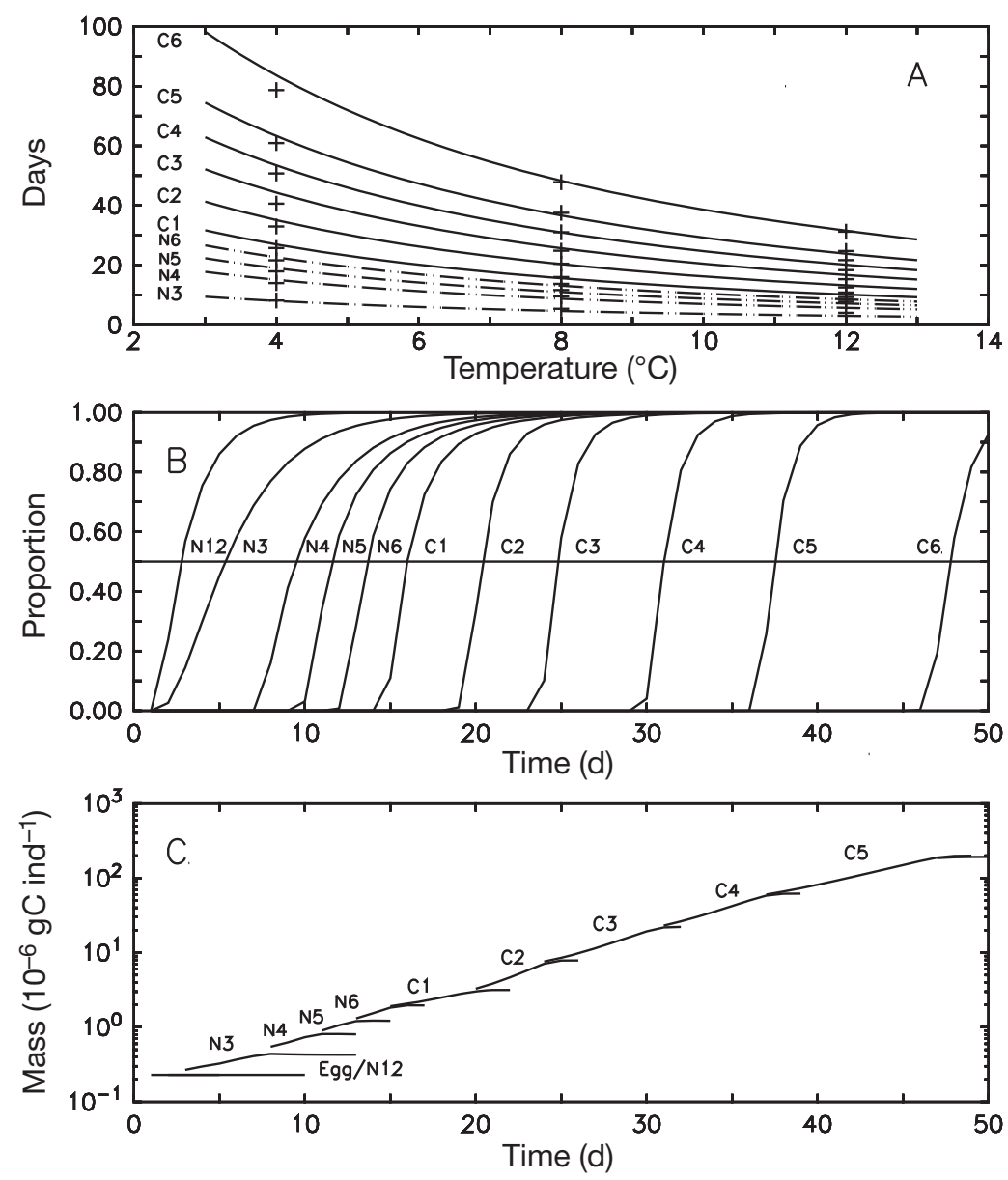

Fig. 2. Calanus finmarchicus. (A) Development time as a Belehrádek function of temperature for N3 to C6 stages (curves, Campbell et al. 2001) and simulated under non-limiting food concentration at 4,8 and $12^{\circ} \mathrm{C}$ by the 0 -dimensional base model (crosses). (B) Cumulative proportions and (C) mass trajectories of the stages simulated at $8^{\circ} \mathrm{C}$ and non-limiting food concentrations 
cumulative percentage of the different stages of Calanus finmarchicus at $8^{\circ} \mathrm{C}$ characterized by a synchronous transfer from one stage to another (Fig. 2B). For the same simulation, the mass structure of the modeled stages from egg to adult female showed an exponential increase in body mass occurring during development (Fig. 2C). The model was also able to reproduce within a few days of difference the observed development times from egg to C5 under variable food conditions (Table 3).

\section{Dormancy}

We tested the ability of our formulation to generate a population in dormancy by allocating $80 \%$ of C5's growth toward lipid storage $\left(p_{1}\right)$ and imposing a threshold of $0.5\left(p_{2}\right)$ to the ratio of lipid carbon to body carbon for the initiation of dormancy. The model was forced by seasonal temperature and food functions reproducing the typical conditions of the upper mixed layer in the northwest GSL (Fig. 3A). The simulation was initiated with 100 eggs laid between Days 70 and 110, with a peak centered on Day 90. This period corresponds to the onset of the phytoplankton bloom, when temperature is greater than $0^{\circ} \mathrm{C}$. Of the first generation of $\mathrm{C} 5$, $58.2 \%$ entered dormancy on Day 174, while $41.8 \%$ moulted into adults (Fig. 3B). The C5d moulted into new adults 120 d later, following a decrease in their body mass during dormancy which brought them to their CMM (Fig. 3B,C). The values of parameters $p_{1}$ and $p_{2}$ applied in this scenario, and the temperature range $\left(6\right.$ to $\left.8^{\circ} \mathrm{C}\right)$ during dormancy did not allow C5d to last until the following spring, generating an unrealistic arousal from dormancy and development to adult stages in late fall.

\section{1-D simulations}

\section{Environmental conditions}

In 1999 and 2000, temperatures higher than $6^{\circ} \mathrm{C}$ remained restricted to the first $20 \mathrm{~m}$ of the water column during summer and fall (Fig. 4A). Maximum surface temperatures exceeded $12^{\circ} \mathrm{C}$ only in July and August. During the growing season, strong gradients in temperature were encountered in the first $10 \mathrm{~s}$ of meters in the northwest GSL owing to the seasonal CIL extending from ca. 30 to $100 \mathrm{~m}$. The
Table 3. Calanus finmarchicus. Development times (d) from egg to copepodite stage $\mathrm{V}$ observed by Campbell et al. (2001) and simulated by the 0-dimensional base model. Food concentrations: $\mathrm{H}$ : high $\left(\sim 350 \mu \mathrm{g} \mathrm{C} \mathrm{l}^{-1}\right)$; M: medium $\left(\sim 40 \mu \mathrm{g} \mathrm{Cl}^{-1}\right)$; L: low $\left(\sim 25 \mu \mathrm{g} \mathrm{Cl}^{-1}\right)$

\begin{tabular}{|lcc|}
\hline $\begin{array}{l}\text { Treatment } \\
\text { (temperature/ } \\
\text { food concentration) }\end{array}$ & $\begin{array}{c}\text { Development time (d) } \\
\text { Campbell et al. (2001) }\end{array}$ & $\begin{array}{c}\text { Model } \\
\text { (present } \\
\text { study) }\end{array}$ \\
\hline $12^{\circ} \mathrm{C} / \mathrm{H}$ & $22-23$ & 21 \\
$8^{\circ} \mathrm{C} / \mathrm{H}$ & 32 & 31 \\
$8^{\circ} \mathrm{C} / \mathrm{M}$ & 46 & 43 \\
$8^{\circ} \mathrm{C} / \mathrm{L}$ & 59 & 63 \\
$4^{\circ} \mathrm{C} / \mathrm{H}$ & 56 & 54 \\
\hline
\end{tabular}

water mass below the CIL is typical of the warmer (ca. $5^{\circ} \mathrm{C}$ ) and saltier Atlantic water. The seasonal pattern in chl a biomass was characterized during both years by a surface spring bloom during the onset of thermal stratification and a subsurface chl a maximum below the thermocline in summer (ca. 20 m). An increase in chl a con-
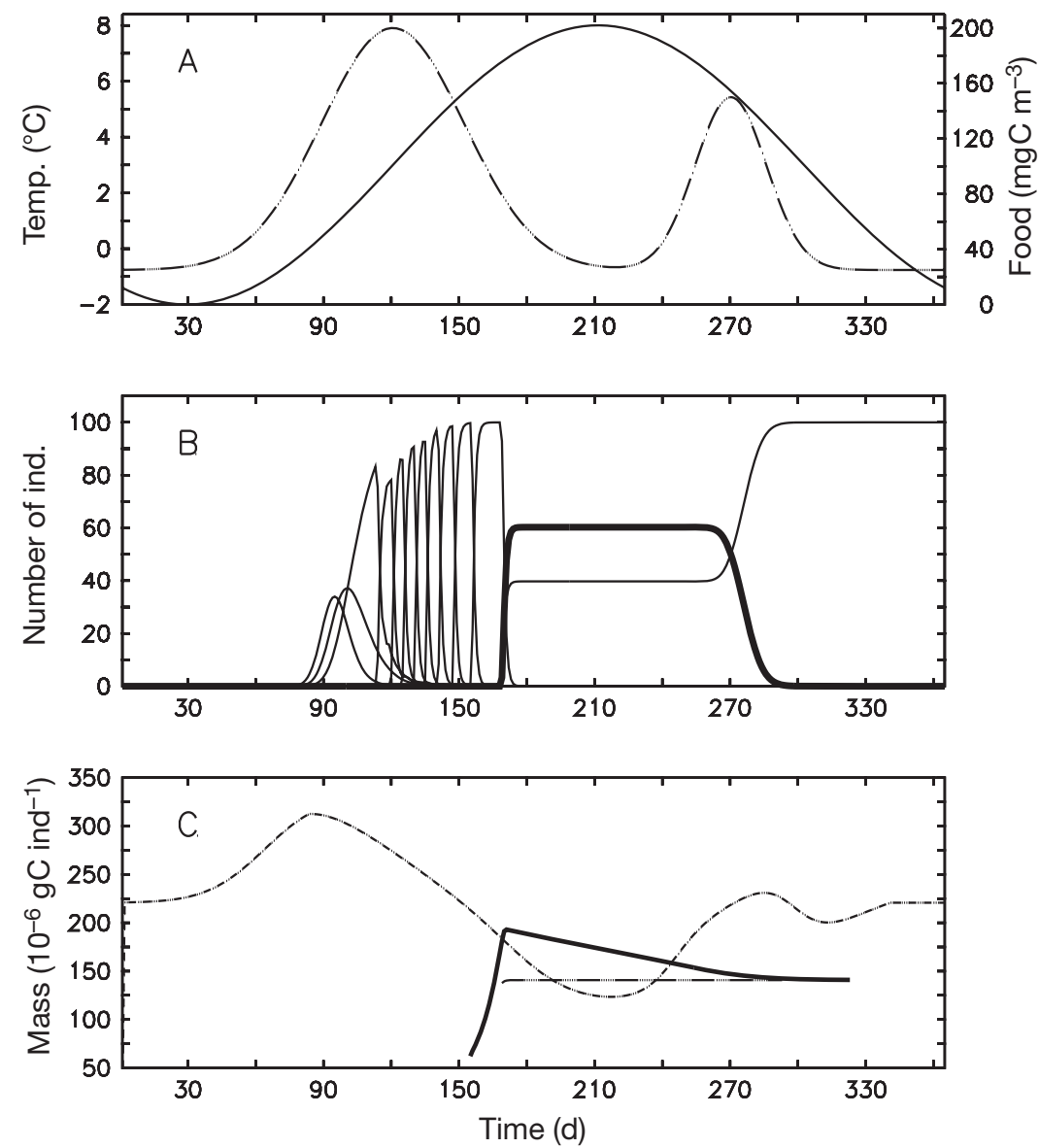

Fig. 3. Calanus finmarchicus. (A) Schematic temperature (solid line) and food (dashed line) forcing for the 0 -dimensional model. (B) Abundances of a simulated cohort initiated with 100 eggs normally distributed about Day 90 (thick line: C5d). (C) Mean mass of total C5 (active and diapausing; solid line), critical moulting mass (CMM) of C5 (dotted line) and CMM of C5d (dashed line) 
Fig. 4. (A) Temperature and (B) chlorophyll a (chl a) forcing used in the 1-dimensional simulations. Measurements (crosses) taken at 2 monitoring stations (Anticosti Gyre and Gaspé Current, Fig. 1) were averaged and then linearly interpolated in space and time. The cold intermediate layer is delimited by the $2^{\circ} \mathrm{C}$ isotherm (solid line) in (A); the depth of maximum chl a concentration is indicated by the solid line in (B)

centration in autumn was also observed in both years (Fig. 4B). The spring bloom was stronger in 1999 (almost $20 \mathrm{mg} \mathrm{chl} \mathrm{a} \mathrm{m} \mathrm{m}^{-3}$ )

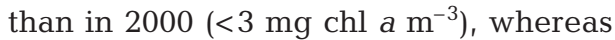
the autumn bloom occurred later and was weaker in 1999 (ca. 4 mg chl a m m $^{-3}$ in Octo-

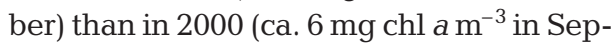
tember). While in July of both years the maxima in chl a biomass were associated with low temperature $\left(<3^{\circ} \mathrm{C}\right)$, contrasting conditions were observed in August of both years. In 1999, the maximum in chl a biomass (ca. $4 \mathrm{mg} \mathrm{m}^{-3}$ ) was associated with low temperature (ca. $3^{\circ} \mathrm{C}$ ), whereas in 2000 a lower maximum in chl a biomass ( $<1 \mathrm{mg}$ $\mathrm{m}^{-3}$ ) was associated with warmer temperature $\left(>8^{\circ} \mathrm{C}\right)$. This interannual variability in subsurface environmental conditions directly influenced the development stages performing DVM (C4, C5 and C6f), while younger stages above the CIL and C5d below the CIL experienced similar conditions between August 1999 and 2000.

\section{Population dynamics}

The optimization procedure used to determine the optimal set of free parameters $p_{1}$ and $p_{2}$ for the 1-D simulation ensured the best correspondence possible between the model results and the observations of copepodite abundance. The optimum free parameters were $87 \%$ of the growth of C5 allocated to the lipid compartment $\left(p_{1}\right)$, and a ratio of lipid carbon to total carbon of $47 \%$ in order to initiate the transfer of C5 to C5d $\left(p_{2}\right)$. We describe hereafter the population dynamics produced by the model using these parameter values for $p_{1}$ and $p_{2}$.

The overwintering stock differed by less than $10 \%$ between autumn 1999 and 2000. However, simulated abundances of C5d were lower by almost 10000 ind. $\mathrm{m}^{-2}$ than the highest observation in December 2000, assuming they were all dormant. The exit from dormancy began in March in both years, a week or 2 later
Temp. $\left({ }^{\circ} \mathrm{C}\right)$
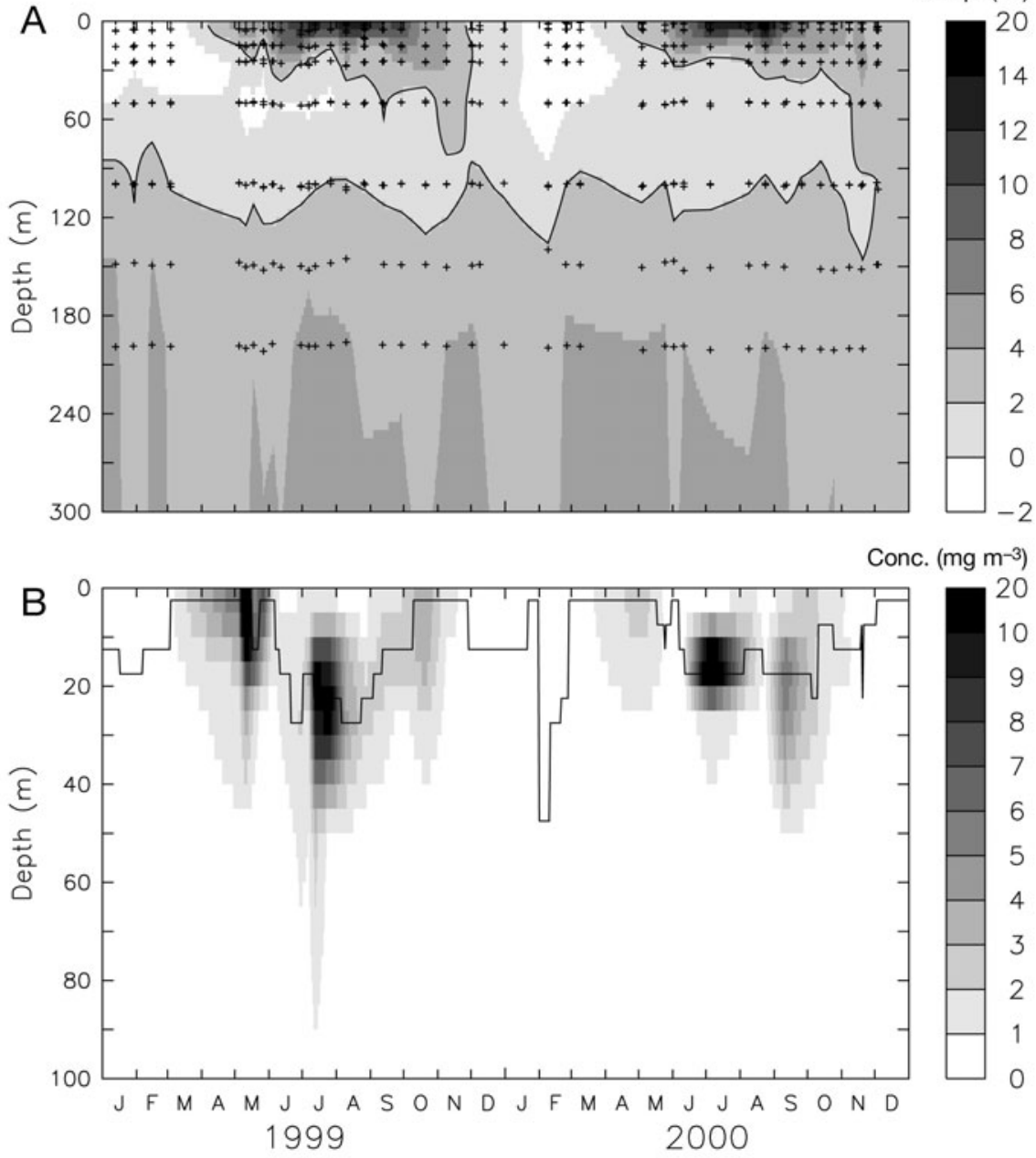

Table 4. Calanus finmarchicus. Observed and simulated timing of dormancy. Observed timings are estimated from data on relative abundances of copepodite stages (see 'Materials and methods'). Dates in parentheses are the sampling dates before and after the above date of onset or emergence from dormancy estimated from observations. Simulated timings are the date of maximum entrance into/exit from dormancy for each simulated generation (G1 to G3). Percentages represent the relative contribution of each simulated generation to the total pool of dormant $\mathrm{C} 5 \mathrm{~d}$ of the given year

\begin{tabular}{|lcc|}
\hline Observations & Model & $\begin{array}{c}\text { Contribution } \\
\text { to dormant } \\
\text { C5d (\%) }\end{array}$ \\
\hline Onset of dormancy & 13 Aug 1999 (G1) & 69 \\
26 Aug 1999 & 30 Sep 1999 (G2) & 8 \\
(7 July-13 September) & 1 Nov 1999 (G3) & 23 \\
9 Aug 2000 & 19 Aug 2000 (G1) & 57 \\
(5 Jul-24 Aug) & 6 Oct 2000 (G2) & 38 \\
\multicolumn{3}{|c|}{ 19 Nov 2000 (G3) } \\
Emergence from dormancy \\
4 Mar 1999 \\
(15 Feb-5 May) & 13 Mar 1999 \\
26 Feb 2000 & 7 Mar 2000 \\
(10 Nov 1999-9 Mar 2000) & \\
\hline
\end{tabular}



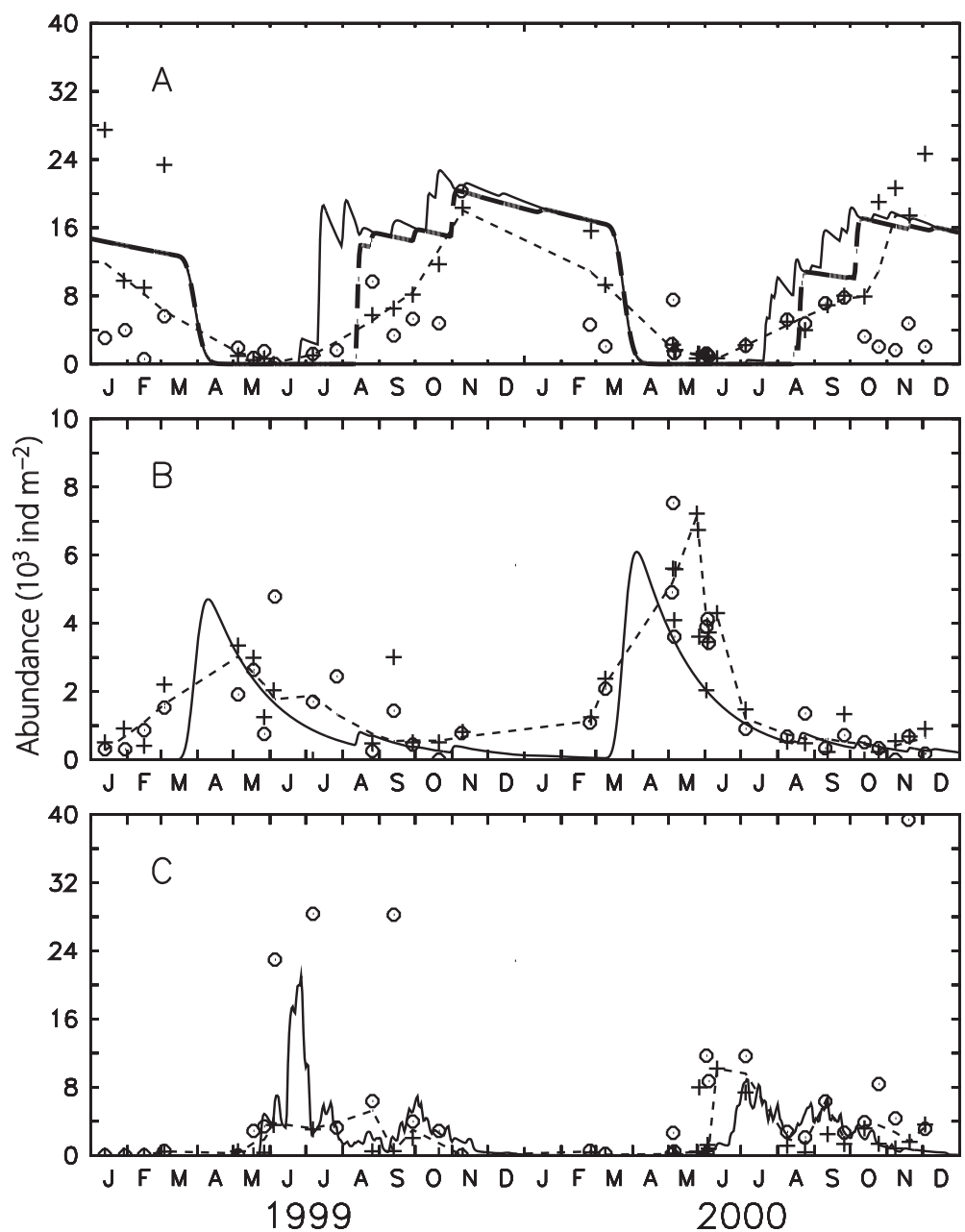

Fig. 5. Calanus finmarchicus. One-dimensional simulation: observed (crosses: Anticosti Gyre; circles: Gaspé Current; short-dashed line: LOWESS smoothing) and simulated abundance of (A) total C5 (solid line) and dormant C5d (dashed line), (B) C6f and (C) C1-3

than estimated from the observed relative proportion of the stages (Fig. 5A, Table 4). The maximum simulated abundance of C6f followed the exit from dormancy in April of both years, whereas the observed maximum occurred in May (Fig. 5B). However, the comparison should be considered with some caution owing to the lack of data in April of both years. The abundance of C6f then slowly decreased until August when a second generation appeared. A peak in the abundance of C1-3 followed the maximum in female abundance in the spring of 1999. Highest values were close to the highest abundance (between 20000 and 30000 ind. $\mathrm{m}^{-2}$ ) observed for the same period of 1999 (Fig. 5C). Abundances of C1-3 were generally underestimated in spring 2000, while the abundance of C5 was generally overestimated in summer. A massive recruitment to $\mathrm{C} 5$ followed the earliest peak in abundance of C1-3 in late June to early July, leading to the appearance of the first generation of $\mathrm{C} 5 \mathrm{~d}$ in August of both years. The estimated timing of the onset of dormancy based on observations was also in August of both years. In the model, C5d always composed more than $50 \%$ of the total C5 stage (active and diapausing) during the following months. Interannual variability in temperature and chl a impacted the subsequent generations of C5d. The second and third generations of C5d appeared, respectively, 1 and $2 \mathrm{wk}$ earlier in 1999 than in 2000, with a different relative contribution to the stock of dormant C5d each year. For instance, the second generation contributed less than the third one in 1999, which was not the case in 2000 (Table 4).

\section{Carbon and lipid content}

The performance of the model can be assessed by a comparison of simulated and observed lipid and carbon body masses in C5. The simulated body mass of $\mathrm{C} 5$ was within the range of observed values during autumn and winter, but in June and July of both years the simulated minimum mass of C5 was almost $50 \mu \mathrm{g} C$ less than observed (Fig. 6A). The mean body mass of C5 increased from August to September-October. The appearance of the second and third generations can be tracked in the slight decrease in average body mass of the C5 stage, caused by the addition of lighter recruits. In autumn, almost all C5 were in dormancy, and their mean body mass decreased steadily from October to the beginning of April when dormancy ceased and moulting to adults occurred. This seasonal pattern produced by the model fitted well the observations at the AG and Rimouski stations (Fig. 6A). The ratio of lipid to body mass was slightly underestimated in 1999 but not in 2000. While young C5 had no lipid content in the model, the minimum proportion of lipid observed in C5 ranged from 20\% in 1999 to almost $40 \%$ in 2000 (Fig. 6B). During the overwintering period between August 1999 and March 2000, C5d lost almost $40 \%$ of their body mass, which translates into a ratio of lipid to body carbon decreasing from 60 to $35 \%$ (Fig. 6B).

\section{Sensitivity analysis}

The model was sensitive to parameters involved in the control of dormancy duration, but less sensitive to parameters controlling abundance (Fig. 7). A 10\% increase or decrease in the parameter of growth alloca- 

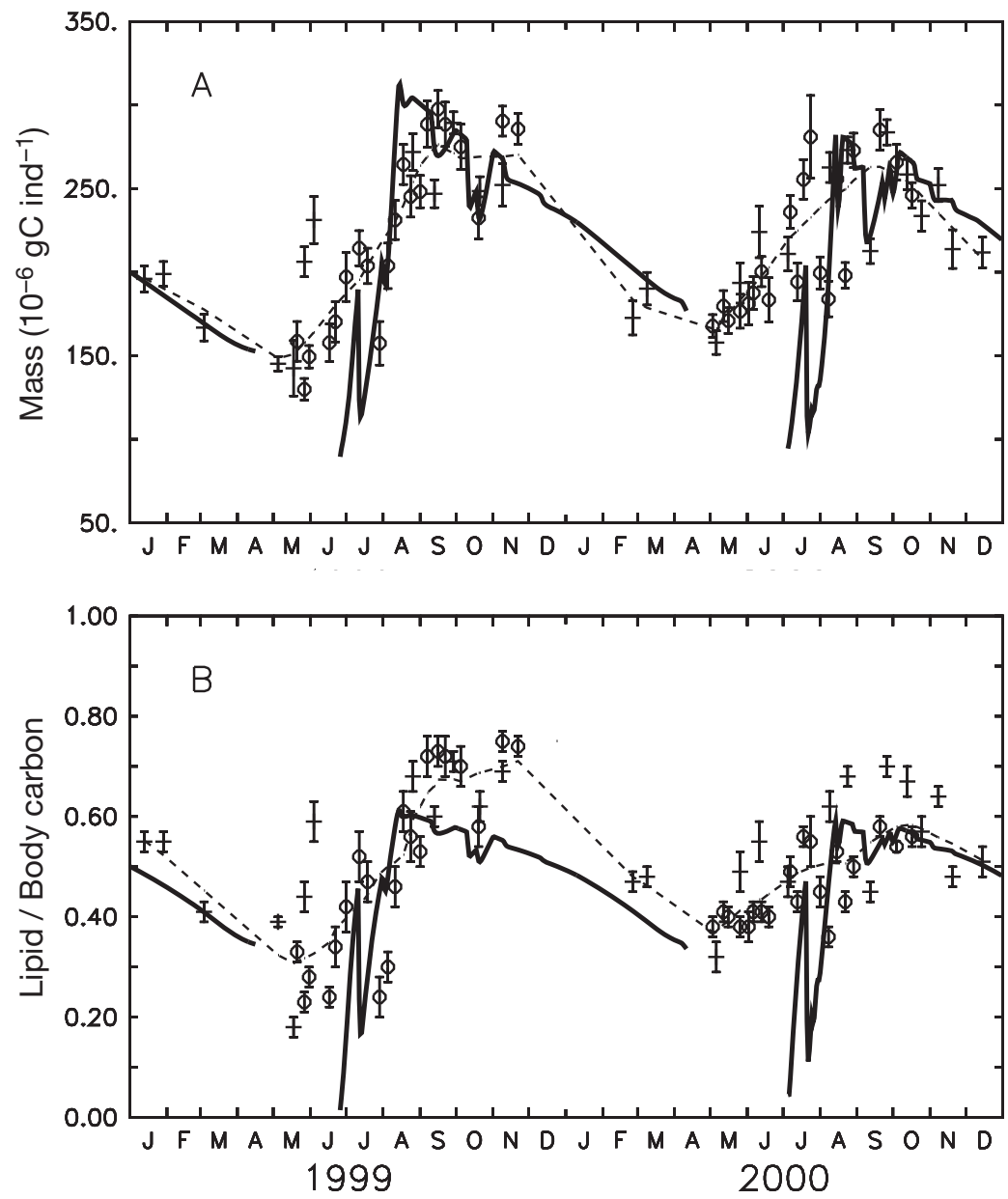

Fig. 6. Calanus finmarchicus. One-dimensional simulation: observed (crosses: Anticosti gyre; circles: Lower Estuary; dotted line: LOWESS smoothing) and simulated (A) mean body carbon content and (B) lipid proportion of total (active and dormant) C5

tion toward lipids in C5 $\left(p_{1}\right)$ resulted in dramatic alteration of the abundance pattern. The basal metabolic rate of lipid consumption in C5d was the second most sensitive parameter. While the former parameter defined the amount of lipid that can be accumulated during the growth of C5 before dormancy, the latter defined the rate of use of lipid during dormancy. Their combination determined the duration of dormancy according to our assumptions. In the case of a $10 \%$ increase in growth allocation toward lipids, the time of exit from dormancy was several months later than expected, which lead to spurious abundances and an uncontrolled increase of the Calanus finmarchicus population at the end of the second year. In the opposite case of a $10 \%$ decrease of lipid growth, the C5d would exit diapause too early in winter and the population would fail. The model responded inversely to an alteration of the basal metabolic rate of lipid consumption in C5d. A $10 \%$ increase in this rate induced an earlier exit from diapause, while a $10 \%$ decrease allowed for a longer diapause period, with drastic consequences on the population dynamics in either case.

\section{DISCUSSION}

While individual-based models allow the study of the evolution of life history strategies at the individual level and their inherent variability (Carlotti \& Wolf 1998, Fiksen \& Carlotti 1998, Fiksen 2000, A. W. Leising et al. unpubl. data), ours is, to our knowledge, the first prognostic model to test a lipid-controlled dormancy mechanism in Calanus finmarchicus at the population level. Our mechanism is based on the internal lipid status of the mean individual as an integrative response to the environment over the time scale of its development until C5. Our model reproduced the observed coincidence of surface-dwelling developing C5 and deep-dwelling diapausing C5 (e.g. Hirche 1983, Miller et al. 1998b), which incited modellers to prescribe a fixed fraction of the C5 from each generation to enter dormancy (e.g. Carlotti \& Wolf 1998, Lynch et al. 1998, Miller et al. 1998a, Tittensor et al. 2003, Zakardjian et al. 2003, Speirs et al. 2006, Slagstad \& Tande 2007). Our model also allowed dormancy to occur long before the environment became adverse, in accordance with theories regarding optimization of life histories in species undergoing a recurrent adverse period (Taylor 1980, Norrbin 1996). Short-term induction of dormancy in response to catastrophic events (e.g. a low food concentration threshold), as proposed by Hind et al. (2000), proved to be inadequate over a wide range of environmental variability at the scale of the North Atlantic (Speirs et al. 2006).

\section{Development formulation}

An accurate determination of the stage duration in a copepod population dynamics model is essential for a correct representation of the life cycle. In our model, the development of Calanus finmarchicus resulted from the interaction between the stage-specific growth rate and the CMM, both nonlinear functions of temperature and food. However, alternate formulations exist. Fiksen (2000) designed a stage-structured biomass model in which growth rate was a function of the temperature-dependent development rate, constant stage- 


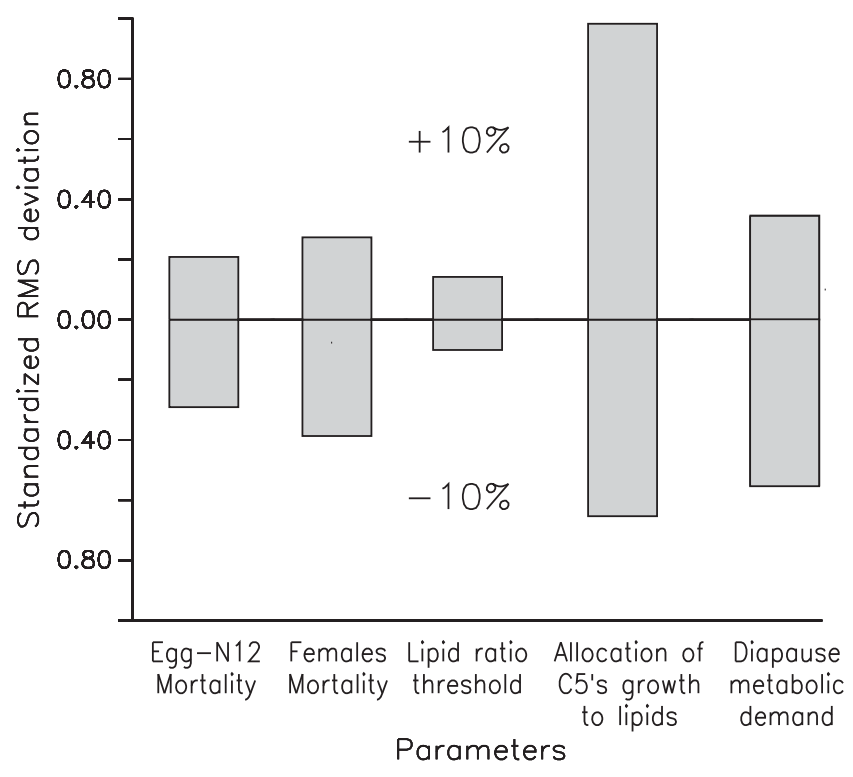

Fig. 7. Calanus finmarchicus. Sensitivity of the 1-dimensional model to selected parameters estimated as the root mean square (RMS) deviation standardized by the mean of the C5d abundance. This metric represents the mean deviation of the results from the simulation with altered parameters $( \pm 10 \%)$ with respect to the base run

specific CMM and food. It is likely that growth and development actually interact to determine the stagespecific CMM (e.g. Aksnes et al. 2006), and data needed to validate such a conceptual model are still lacking. However, the strength and quality of the empirical relationships available for both stage-specific growth rates and CMM of $C$. finmarchicus allows our model to simulate realistic population dynamics and biomass with the benefit of a light computational cost and no numerical diffusion causing prematuration.

\section{Mortality}

In addition to the high population EPR associated with the first generation of C6f in spring, the use of constant daily mortality rates in our model was partly responsible for the emergence of a strong first generation of $\mathrm{C} 5$ in both years. The sensitive interaction between development duration and daily mortality in the early development stages appeared critical for the population dynamics of Calanus finmarchicus. The early summer stratification of the water column led to a sharp increase in surface temperature (Fig. 2A), which allowed the growth rate of surface-dwelling nauplii to be more than twice as high in June than in May. This faster development resulted in a decrease in cumulative mortality during the early stages, hence generating a recruitment burst to the following copepodite stages (Fig. 5C). While the model was sensitive to changes in mortality of young stages (Fig. 7), it was even more sensitive to the mortality of females, owing to their direct influence on the reproductive output of the population. Mortality is actually time- and spacedependent (Ohman et al. 2004, Plourde et al. 2009), and the dependence of mortality on season, region and depth could dramatically alter abundance patterns (e.g. Fiksen \& Carlotti 1998, Neumann \& Kremp 2005, Speirs et al. 2006, Plourde et al. 2009). However, exploring further the complex issue of variable mortality patterns was beyond the scope of the present study.

\section{Advection}

Advection in the northwest GSL could account for the few discrepancies between the simulated and observed abundances of C6f in spring and C5 in summer. The surface circulation in the northwest GSL is characterized by an offshore anticyclonic gyre (AG). However, interactions with a buoyancy-driven baroclinic coastal current along the Gaspé Peninsula (GC) lead to numerous instabilities. The mean residual surface circulation in the northwest GSL heads downstream toward the Atlantic (Tang 1980, Mertz et al. 1988, Saucier et al. 2003). The deep residual circulation prevailing in the GSL system is less variable and heads upstream (Saucier et al. 2003, 2009). Therefore, flushing from the surface layer could contribute to the delay between the simulated and observed maximum of C6f in spring when the freshet of the St. Lawrence River is at a maximum, as well as the low observed abundance of $\mathrm{C} 5$ in early summer. Later in August, while the dormant stock formed according to both estimates from observations and model results (Table 4), the slow upstream advection of the deep-dwelling C5d could result in the increased abundance of $\mathrm{C} 5$ that was observed. Our model could be coupled to a 3-dimensional (3-D) regional circulation model to test these predictions.

\section{Carbon and lipid content}

Biomass provided the principal source of data to validate the model. A comparison between simulated and observed lipid content in C5 was crucial to estimate the suitability of our mechanistic control of dormancy through lipid accumulation and metabolism. The body mass and lipid fraction of simulated C5 were within the range of observed values (Fig. 6). Simulated C5 performed DVM and developed in an environment whose median temperatures in summer were $1.3^{\circ} \mathrm{C}$ in August 1999 and $1.6^{\circ} \mathrm{C}$ in August 2000. The cold temperature 
in the CIL could explain in part why the body mass and lipid content of Calanus finmarchicus C5 from the northwest GSL were almost twice as high as the values reported elsewhere in the North Atlantic (e.g. Carlotti et al. 1993, Heath et al. 2004, Saumweber \& Durbin 2006), except in a few Scandinavian fjords (Hirche 1983) and in the Labrador Sea (e.g. Pepin \& Head 2009). Another contributing factor could be the sustained non-limiting food concentration ( $>1 \mathrm{mg} \mathrm{chl} \mathrm{a}$ $\mathrm{m}^{-3}$ ) in summer in the northwest GSL (Fig. 2B). In the Gulf of Maine/Georges Bank area, in situ body masses
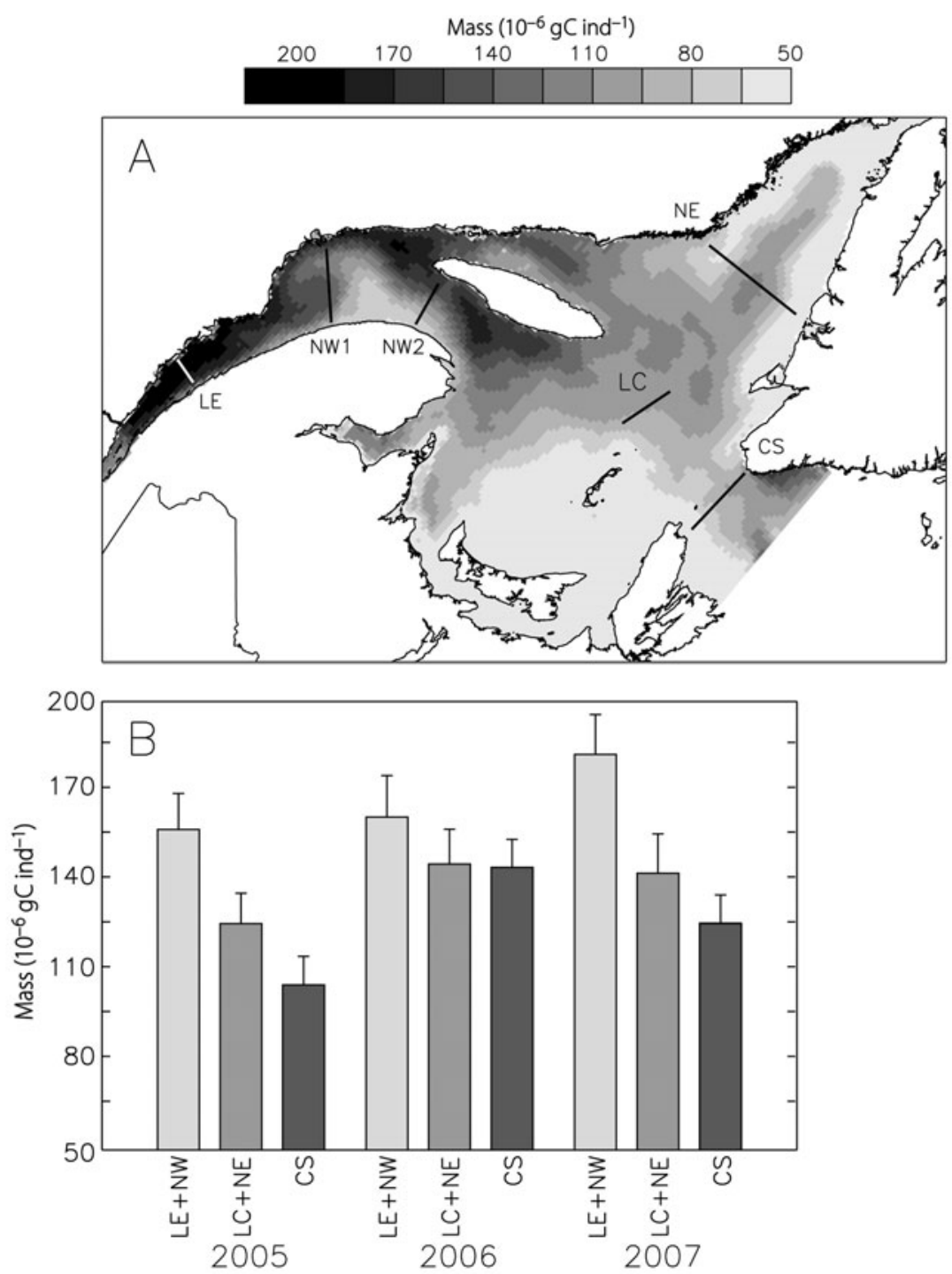

Fig. 8. Calanus finmarchicus. (A) Carbon content of C5 ( $\mu \mathrm{g} \mathrm{C}$ ind ${ }^{-1}$ ) simulated according to conditions of temperature and food provided by a 3dimensional nutrient-phytoplankton-zooplankton-detritus model of the Gulf of St. Lawrence (Le Fouest et al. 2005, 2006). Simulated C5s entered diapause in August of 1999 but were sampled in November. (B) Carbon content of $\mathrm{C} 5$ derived from prosome length observations obtained during the Atlantic Zone Monitoring Program transects of November 2005, 2006 and 2007. CS: Cabot Strait; LC: Laurentian Chanel; LE: Lower Estuary; NE: Northeast Gulf; NW: Northwest Gulf of C5 were half that of the lowest masses obtained from individuals developing in a controlled environment with a similar temperature range, but non-limiting food concentrations (Campbell et al. 2001).

The minimum in body carbon (ca. $175 \mu \mathrm{g} \mathrm{C}$ ) and ratio of lipid to body carbon (ca. 0.35) simulated for C5 in April at the end of the dormancy period corresponded to the range of the observations. Moreover, both measurements compared well with the range of carbon content of immature females arising from dormancy in spring in the lower St. Lawrence Estuary (160 to $220 \mu \mathrm{g}$ C female $^{-1}$, Runge \& Plourde 1996), and the associated range of relative oil sac volume $(0.15$ to 0.3 , Plourde \& Runge 1993). These relative oil sac volumes values are equivalent to a range of lipid carbon of 50 to $70 \mu \mathrm{g} \mathrm{C}$ in immature females newly aroused from dormancy. This amount of carbon corresponds to several estimations of the minimum lipid carbon needed by diapausing C5 for the terminal moult and maturation of the gonads, ranging from $40 \mu \mathrm{g} C$ (Rey-Rassat et al. 2002) to $70 \mu \mathrm{g} C$ (Ingvarsdóttir et al. 1999).

The actual process of lipid accumulation is already well established in C4, contrary to our model, where no lipid compartment was accounted for in C4. This had implications for the parameterisation of the allocation of growth toward lipids in C4. As all of the $\mathrm{C} 4$ body mass was allocated to the initial structural mass of newly moulted C5 (Eq. 4, Table 1), C5 required a higher proportion of its growth to be allocated to lipid accumulation in order to accumulate the necessary amount to meet metabolic costs associated with dormancy. The lipid compartment should be taken into account in stage $\mathrm{C} 4$ and new data about the condition of individuals are needed, especially as the control of dormancy entry could involve the C4 stage (Johnson et al. 2008, A. W. Leising et al. unpubl. data).

\section{Regional and interannual variability}

Within the GSL and the Newfoundland and Scotian shelves, the dormancy window varies by several months (Johnson et al. 2008). This could result from spatial variability in the lipid content in diapausing individuals. Application of Eq. (12) (Table 1) of our model on temperature and phytoplankton results from a 3-D bio- 
physical nutrient-phytoplankton-zooplankton-detritus model of the GSL (LeFouest et al. 2005, 2006) produced a regional gradient of $\mathrm{C} 5$ body mass (Fig. 8A). The CMMs of the C5 stage were computed according to the average temperature and maximum phytoplankton carbon found between 0 and $100 \mathrm{~m}$ in August, when the major C5d recruitment event occurred in the model. Assuming a lipid proportion of $60 \%$ (Fig. 6B), the carbon content of C5 was then adjusted according to the projected consumption of lipid between August and November, in order to compare these estimates with observation obtained during November 2005, 2006 and 2007 (S. Plourde \& G. Parent unpubl. data). The in situ carbon content was estimated from 2 empirical relationships between prosome length and dry weight, and dry weight and carbon content (S. Plourde unpubl. data). Values were then averaged between the lower estuary and both northwestern transects, and between the central Laurentian Channel and the northeast transects, while the Cabot Strait transect was treated separately (Fig. 8B). An eastward negative gradient in carbon content of the C5 similar to the simulation results was observed each year. Differences between simulated and observed values remained within the range of observed interannual variability. The plastic response of our model to environmental variability, and its low computational cost, allows it to be readily embedded in an Eulerian general circulation model (e.g. Fennel \& Neumann 2003) in order to test its ability to produce a realistic phenology for Calanus finmarchicus populations undergoing strong influences from the hydrodynamics in the continental shelf of the Northwest Atlantic (Miller et al. 1998a, Gentleman 2000, Plourde et al. 2001, Zakardjian et al. 2003, Johnson et al. 2006).

Acknowledgements. The authors thank the AZMP from Fisheries and Oceans Canada for providing the data, and gratefully acknowledge P. Joly for the carbon and lipid content analyses. This work was partly supported by a NSERC fellowship to F.M. and by NSF awards OCE-0733910 and OCE0815336 to J. A. Runge. Results were partly presented by F.M. at the 4th International Zooplankton Production Symposium held between 28 May and 1 June 2007 in Hiroshima, Japan. The authors gratefully acknowledge the constructive comments provided by J. A. Runge, A. Leising, A. Pershing, N. Record and several anonymous reviewers. The authors wish to honour the memory of F. Saucier, who gracefully supported this project and provided insightful comments until the end.

\section{LITERATURE CITED}

Aksnes DL, Troedsson C, Thompson EM (2006) Integrating developmental clocking and growth in a life-history model for the planktonic chordate Oikopleura dioica. Mar Ecol Prog Ser 318:81-88

Campbell RG, Wagner MM, Teegarden GJ, Boudreau CA,
Durbin EG (2001) Growth and development rates of the copepod Calanus finmarchicus reared in the laboratory. Mar Ecol Prog Ser 221:161-183

Carlotti F, Sciandra A (1989) Population dynamics model of Euterpina acutifrons (Copepoda: Harpacticoida) coupling individual growth and larval development. Mar Ecol Prog Ser 56:225-242

Carlotti F, Wolf K (1998) A Lagrangian ensemble model of Calanus finmarchicus coupled with a 1D ecosystem model. Fish Oceanogr 7:191-204

Carlotti F, Krause M, Radach G (1993) Growth and development of Calanus finmarchicus related to the influence of temperature: experimental results and conceptual model. Limnol Oceanogr 38:1125-1134

Christian J (2007) Advection in plankton models with variable elemental ratios. Ocean Dyn 57:63-71

Durbin EG, Campbell RG, Gilman SL, Durbin AG (1995) Diel feeding behavior and ingestion rate in the copepod Calanus finmarchicus in the southern Gulf of Maine during late spring. Cont Shelf Res 15:539-570

> Durbin EG, Runge JA, Campbell RG, Garrahan PR, Casas MC, Plourde S (1997) Late fall-early winter recruitment of Calanus finmarchicus on Georges Bank. Mar Ecol Prog Ser 151:103-114

> Fennel W (2001) Modeling of copepods with links to circulation models. J Plankton Res 23:1217-1232

Fennel W, Neumann T (2003) Variability of copepods as seen in a coupled physical-biological model of the Baltic Sea. ICES Mar Sci Symp 219:208-219

- Fiksen O (2000) The adaptive timing of dormancy: a search for evolutionarily robust strategies in Calanus finmarchicus. ICES J Mar Sci 57:1825-1833

Fiksen O, Carlotti F (1998) A model of optimal life history and diel vertical migration in Calanus finmarchicus. Sarsia 83: $129-147$

Gentleman W (2000) Factors controlling the seasonal abundance and distribution of Calanus finmarchicus in the Gulf of Maine/Georges Bank region. PhD dissertation, Dartmouth College, Hanover, NH

Gislason A, Eiane K, Reynisson P (2007) Vertical distribution and mortality of Calanus finmarchicus during overwintering in oceanic waters southwest of Iceland. Mar Biol 150: $1253-1263$

Harris RP, Irigoien X, Head RN, Rey C and others (2000) Feeding, growth, and reproduction in the genus Calanus. ICES J Mar Sci 57:1708-1726

Harvey M, St-Pierre J, Devine L, Gagné A, Gagnon Y, Beaulieu M (2005) Oceanographic conditions in the Estuary and the Gulf of St. Lawrence during 2004: zooplankton. Research Document 2005/043, Department of Fisheries and Oceans, Canadian Science Advisory Secretariat, Mont-Joli

Hassett RP (2006) Physiological characteristics of lipid-rich 'fat' and lipid-poor 'thin' morphotypes of individual Calanus finmarchicus C5 copepodites in nearshore Gulf of Maine. Limnol Oceanogr 51:997-1003

> Head E, Pepin P (2007) Variations in overwintering depth distributions of Calanus finmarchicus in the slope waters of the NW Atlantic continental shelf and the Labrador Sea. J Northwest Atl Fish Sci 39:49-69

> Heath MR, Boyle PR, Gislason A, Gurney WSC and others (2004) Comparative ecology of over-wintering Calanus finmarchicus in the northern North Atlantic, and implications for life-cycle patterns. ICES J Mar Sci 61:698-708

Hind A, Gurney WSC, Heath M, Bryant AD (2000) Overwintering strategies in Calanus finmarchicus. Mar Ecol Prog Ser 193:95-107 
Hirche HJ (1983) Overwintering of Calanus finmarchicus and Calanus helgolandicus. Mar Ecol Prog Ser 11:281-290

Hirche HJ (1996a) The reproductive biology of the marine copepod, Calanus finmarchicus: a review. Ophelia 44: 111-128

Hirche HJ (1996b) Dormancy in the marine copepod Calanus finmarchicus: a review. Ophelia 44:129-143

Hirche HJ, Meyer U, Niehoff B (1997) Egg production of Calanus finmarchicus: effect of temperature, food and season. Mar Biol 127:609-620

Hygum BH, Rey C, Hansen BW (2000a) Growth and development rates of Calanus finmarchicus nauplii during a diatom spring bloom. Mar Biol 136:1075-1085

> Hygum BH, Rey C, Hansen BW, Tande K (2000b) Importance of food quantity to structural growth rate and neutral lipid reserves accumulated in Calanus finmarchicus. Mar Biol 136:1057-1073

Ingvarsdóttir A, Houlihan DF, Heath MR, Hay SJ (1999) Seasonal changes in respiration rates of copepodite stage $\mathrm{V}$ Calanus finmarchicus (Gunnerus). Fish Oceanogr 8:73-83

Irigoien X (2004) Some ideas about the role of lipids in the life cycle of Calanus finmarchicus. J Plankton Res 26:259-263

Irigoien X, Head R, Klenke U, Meyer-Harms B and others (1998) A high frequency time series at weathership M, Norwegian Sea, during the 1997 spring bloom: feeding of adult female Calanus finmarchicus. Mar Ecol Prog Ser 172:127-137

Johnson CL, Pringle J, Chen C (2006) Transport and retention of dormant copepods in the Gulf of Maine. Deep-Sea Res II 53:2520-2536

> Johnson CL, Leising AW, Runge JA, Head EJH, Pepin P, Plourde S, Durbin EG (2008) Characteristics of Calanus finmarchicus dormancy patterns in the Northwest Atlantic. ICES J Mar Sci 65:339-350

Jónasdóttir S (1999) Lipid content of Calanus finmarchicus during overwintering in the Faroe-Shetland Channel. Fish Oceanogr 8:61-72

Kiørboe T (2006) Sex, sex-ratios, and the dynamics of pelagic copepod populations. Oecologia 148:40-50

LeFouest V, Zakardjian B, Saucier F, Starr M (2005) Seasonal versus synoptic variability in planktonic production in a high-latitude marginal sea: the Gulf of St. Lawrence (Canada). J Geophys Res C 110:1-21

- LeFouest V, Zakardjian B, Saucier F, Cizmeli S (2006) Application of SeaWIFS- and AVHRR-derived data for mesoscale and regional validation of a 3-D high-resolution physical-biological model of the Gulf of St. Lawrence (Canada). J Mar Syst 60:30-50

Lipscomb WH, Hunke EC (2004) Modeling sea ice transport using incremental remapping. Mon Weather Rev 132: 1341-1354

Lynch DR, Gentleman WC, McGillicuddy DJ, Davis CS (1998) Biological/physical simulations of Calanus finmarchicus population dynamics in the Gulf of Maine. Mar Ecol Prog Ser 169:189-210

Mackas DL, Batten S, Trudel M (2007) Effects on zooplankton of a warmer ocean: recent evidence from the Northeast Pacific. Prog Oceanogr 75:223-252

McLaren IA, Head E, Sameoto DD (2001) Life cycles and seasonal distributions of Calanus finmarchicus on the central Scotian Shelf. Can J Fish Aquat Sci 58:659-670

> Mertz G, El-Sabh MI, Proulx D, Condal AR (1988) Instability of a buoyancy-driven coastal jet: The Gaspé Current and its St. Lawrence precursor. J Geophys Res C 93:6885-6893

Miller CB, Lynch DR, Carlotti F, Gentleman W, Lewis C5W (1998a) Coupling of an individual-based population dynamic model of Calanus finmarchicus to a circulation model for the Georges Bank region. Fish Oceanogr 7: 219-234

Miller CB, Morgan CA, Prahl FG, Sparrow MA (1998b) Storage lipids of the copepod Calanus finmarchicus from Georges Bank and the Gulf of Maine. Limnol Oceanogr 43:488-497

Miller CB, Crain JA, Morgan CA (2000) Oil storage variability in Calanus finmarchicus. ICES J Mar Sci 57:1786-1799

Neumann T, Kremp C (2005) A model study with lightdependent mortality rates of copepod stages. J Mar Syst 56:416-434

Norrbin MF (1996) Timing of dormancy in relation to the onset of winter in the high-latitude copepods Pseudocalanus acuspes and Acartia longiremis. Mar Ecol Prog Ser 142:99-109

> Ohman MD, Runge JA, Durbin EG, Field DB, Niehoff B (2002) On birth and death in the sea. Hydrobiologia 480:55-68

Ohman MD, Eiane K, Durbin EG, Runge JA, Hirche HJ (2004) A comparative study of Calanus finmarchicus mortality patterns at five localities in the North Atlantic. ICES J Mar Sci 61:687-697

> Pepin P, Head EJH (2009) Seasonal and depth-dependent variations in the size and lipid contents of stage 5 copepodites of Calanus finmarchicus in the waters of the Newfoundland Shelf and the Labrador Sea. Deep-Sea Res Part I 56:989-1002

> Piñeiro G, Perelman S, Guerschman JP, Paruelo JM (2008) How to evaluate models: observed vs. predicted or predicted vs. observed? Ecol Model 216:316-322

> Planque B, Hays GC, Ibanez F, Gamble JC (1997) Large scale spatial variations in the seasonal abundance of Calanus finmarchicus. Deep-Sea Res Part I 44:315-326

Plourde S, Runge JA (1993) Reproduction of the planktonic copepod Calanus finmarchicus in the Lower St. Lawrence Estuary: relation to the cycle of phytoplankton production and evidence for a Calanus pump. Mar Ecol Prog Ser 102: $217-227$

Plourde S, Joly P, Runge JA, Zakardjian B, Dodson JJ (2001) Life cycle of Calanus finmarchicus in the lower St. Lawrence Estuary: the imprint of circulation and late timing of the spring phytoplankton bloom. Can J Fish Aquat Sci 58:647-658

> Plourde S, Maps F, Joly P (2009) Mortality and survival in early stages control recruitment in Calanus finmarchicus. J Plankton Res 31:371-388

Rey-Rassat C, Irigoien X, Harris R, Carlotti F (2002) Energetic cost of gonad development in Calanus finmarchicus and C. helgolandicus. Mar Ecol Prog Ser 238:301-306

Ringuette M, Castonguay M, Runge JA, Gregoire F (2002) Atlantic mackerel (Scomber scombrus) recruitment fluctuations in relation to copepod production and juvenile growth. Can J Fish Aquat Sci 59:646-656

Rivkin RB, Legendre L, Deibel D, Tremblay JE and others (1996) Vertical flux of biogenic carbon in the ocean: Is there food web control? Science 272:1163-1166

Runge JA, Plourde S (1996) Fecundity characteristics of Calanus finmarchicus in coastal waters of eastern Canada. Ophelia 44:171-187

Saucier FJ, Roy F, Gilbert D, Pellerin P, Ritchie H (2003) Modeling the formation and circulation processes of water masses and sea ice in the Gulf of St. Lawrence, Canada. J Geophys Res 108:3269

Saucier FJ, Roy F, Senneville S, Smith G, Lefaivre D, Zakardjian B, Dumais JF (2009) Modelling of the circulation in the Estuary and Gulf of St. Lawrence in response to variations in fresh water runoff and winds. Rev Sci Eau 21:525-542 (in French with English Abstract) 
Saumweber WJ, Durbin EG (2006) Estimating potential dormancy duration in Calanus finmarchicus. Deep-Sea Res Part II 53:2597-2617

Simard Y, Lacroix G, Legendre L (1985) In situ twilight grazing rhythm during diel vertical migrations of a scattering layer of Calanus finmarchicus. Limnol Oceanogr 30: 598-606

Slagstad D, Tande KS (2007) Structure and resilience of overwintering habitats of Calanus finmarchicus in the eastern Norwegian Sea. Deep-Sea Res II 54:2702-2715

Speirs DC, Gurney WSC, Heath MR, Horbelt W, Wood SN, de Cuevas BA (2006) Ocean-scale modelling of the distribution, abundance, and seasonal dynamics of the copepod Calanus finmarchicus. Mar Ecol Prog Ser 313: 173-192

Stegert C, Kreus M, Carlotti F, Moll A (2007) Parameterisation of a zooplankton population model for Pseudocalanus elongatus using stage durations from laboratory experiments. Ecol Modell 206:213-230

Tang CL (1980) Mixing and circulation in the northwestern Gulf of St. Lawrence: a study of a buoyancy-driven current system. J Geophys Res 85:2787-2796

Tarrant AM, Baumgartner MF, Verslycke T, Johnson CL

Editorial responsibility: Alejandro Gallego,

Aberdeen, UK
(2008) Differential gene expression in diapausing and active Calanus finmarchicus (Copepoda). Mar Ecol Prog Ser 355:193-207

Taylor F (1980) Optimal switching to dormancy in relation to the onset of winter. Theor Popul Biol 18:125-133

Therriault J, Petrie B, Pepin P, Gagnon J and others (1998) Proposal for a northwest zonal monitoring program. Can Tech Rep Hydrogr Ocean Sci 194:1-64

Tittensor DP, DeYoung B, Tang CL (2003) Modelling the distribution, sustainability and dormancy emergence timing of the copepod Calanus finmarchicus in the Labrador Sea. Fish Oceanogr 12:299-316

Zakardjian BA, Runge J, Plourde S, Gratton Y (1999) A biophysical model of the interaction between vertical migration of crustacean zooplankton and circulation in the Lower St Lawrence Estuary. Can J Fish Aquat Sci 56: $2420-2432$

Zakardjian BA, Sheng J, Runge JA, McLaren I, Plourde S, Thompson KR, Gratton Y (2003) Effects of temperature and circulation on the population dynamics of Calanus finmarchicus in the Gulf of St. Lawrence and Scotian Shelf: study with a coupled, three-dimensional hydrodynamic, stage-based life history model. J Geophys Res 108:8016

Submitted: November 4, 2008; Accepted: February 3, 2010 Proofs received from author(s): March 15, 2010 